\title{
PENGUATAN EKONOMI KREATIF BERBASIS SUMBERDAYA DESA DI KAWASAN PESISIR
}

\author{
Anwar Sadat ${ }^{1}$, Hamdan Hidayat ${ }^{2}$, Asril Midu ${ }^{3}$, Hasriana ${ }^{4}$ \\ ${ }^{1}$ Dosen Program Studi Ilmu Pemerintahan, Fakultas Ilmu Sosial dan Ilmu Politik \\ ${ }^{234}$ Mahasiswa Program Studi Ilmu Pemerintahan, Fakultas Ilmu Sosial dan Ilmu Politik \\ Universitas Muhammadiyah Buton \\ Email: ${ }^{1}$ anwarsadat685@gmail.com
}

Submitted: 12 Agustus 2020 Accepted:18 April 2021 Published: 30 April 2021

\begin{abstract}
Abstrak: Desa Bahari III memiliki berbagai potensi sumberdaya yang pemanfaatannya belum optimal. Salah satu potensi yang penting diperhatikan adalah sumberdaya manusia dan kemampuan kreatifitas yang dimilikinya. Manusia mampu menciptakan sumberdaya terbatas dan bernilai jual rendah menjadi sumberdaya yang bernilai ekonomis tinggi. Desa Bahari III memiliki kekayaan sumberdaya alam yang sangat potensial antara lain kelapa, perikanan, dan wisata bahari. Penyuluhan ini bertujuan memotivasi masyarakat untuk mengembangkan kreatifitasnya sehingga dapat mengembangkan sumberdaya yang potensial tersebut. Hasil pengabdian yang dilakukan masyarakat yang semula belum mengerti membaca peluang yang ada setelah mendapat penyuluhan mereka antusias ingin mengembangkan berbagai kreatifitasnya sehingga dapat memanfaatkan sumberdaya yang terdapat di desa menjadi produk yang bernilai ekonomi tinggi. Setelah mengikuti penyuluhan masyarakat juga membuat suatu kelembagaan yang mendukung tujuan tersebut yakni dengan mendirikan rumah kreatif masyarakat.
\end{abstract}

Kata Kunci: Ekonomi Kreatif, Sumberdaya Desa, Kawasan Pesisir 


\section{PENDAHULUAN}

Tingginya jumlah penduduk pada usia produktif merupakan suatu potensi sumberdaya manusia yang bisa mendukung kemajuan dan keberlanjutan pembangunan desa apabila diberdayakan secara maksimal. Kehidupan sosial ekonomi rumah tangga nelayan Desa Bahari III tidak jauh berbeda dengan karakteristik rumah tangga nelayan di kawasan pesisir pada umumnya dimana sebagian besar mereka masih tergolong dalam struktur sosial ekonomi berskala kecil, berorientasi subsisten serta berteknologi sederhana serta memiliki keterbatasan pendapatan, pendidikan dan keterampilan sehingga memiliki kecenderungan terhadap kondisi kemiskinan.

Keuntungan-keuntungan ekonomi dari pemanfaatan sumberdaya-sumberdaya pesisir (kelautan dan perikanan) yang terdapat di sekitar Desa Bahari III lebih dinikmati oleh kelompok masyarakat tertentu yang memiliki modal seperti pemilik-pemilik kapal dan pengusahapengusahan perikanan berskala menengah ke atas. Aktifitas sosial ekonomi kelas menengah ini dikhawatirkan akan menimbulkan degradasi sumberdaya terutama bagi keberlanjutan mata pencaharian rumah tangga miskin berskala kecil.

Kekayaan sumberdaya alam pesisir yang terdapat di Desa Bahari III yang dimanfaatkan sebagai sumber pendapatan masyarakat adalah pohon kelapa. Dengan kearifan lokal yang ada di daerah sendiri, masyarakat harus mampu mengembangkan kreatifitasnya, dan mendatangkan impak positif bagi perekonomian masyarakat Desa Bahari III.

Keterbatasan sumberdaya alam kawasan pesisir untuk meningkatkan kesejahteraan masyarakat setempat membutuhkan banyak ide-ide kreatif dari masyarakat dalam pemanfaatan keterbatasan sumberdaya tersebut. Ide- ide kreatif tersebut dapat dituangkan dalam bentuk produk-produk kreatif yang dapat meningkatkan kesejahteraan.

Desa Bahari III memiliki potensi wilayah yang cukup strategis, dengan kekayaan sumberdaya alam yang belum dimanfaatkan secara optimal serta potensi sumberdaya manusia yang bisa mendukung ekonomi kreatif di pedesaan. Di sisi lain aktifitas sosial ekonomi yang selama ini dilakukan masyarakat desa belum mengarah dan berfokus pada penguatan ekonomi kreatif. Karena itu upaya mengeksplorasi sumberdaya manusia melalui pengembangan ide-ide 
kreatifnya diharapkan akan dapat menciptakan penguatan ekonomi kreatif di pedesaan serta meningkatkan kesejahteraan masyarakat. Untuk itu masyarakat desa perlu mendapatkan penyuluhan mengenai pemahaman mengenai ruang lingkup ekonomi kreatif dan pengetahuan bagaimana mengembangkannya di wilayah pedesaan.

Sesuai tujuan tersebut di atas perlu dilakukan kegiatan pemberdayaan masyarakat di Desa Bahari III untuk menjawab beberapa pertanyaan berikut yaitu:

1. Apa saja potensi sumberdaya desa yang dapat dimanfaatkan oleh masyarakat mendukung ekonomi kreatif untuk tujuan peningkatan kesejahteraan?

2. Sejauh mana keinginan masyarakat untuk meningkatkan pendapatannya melalui optimalisasi pemanfaatan sumberdaya desa

Kegiatan PKM ini dilaksanakan oleh Dosen dan Mahasiwa Program Studi Ilmu Pemerintahan Fakultas Ilmu Sosial dan Ilmu Politik Universitas Muhammadiyah Buton. Kegiatan pengabdian ini tidak hanya sebagai perwujudan tanggung jawab dosen untuk melaksanakan tanggungjawab dalam hal tridharma perguruan tinggi yang dilaksanakan rutin setiap tahun pada masyarakat, melainkan juga sebagai sebuah kegiatan yang memberikan pengalaman kepada mahasiswa untuk belajar dan menerapkan keterampilan sesuai bidang keahlian yang dipelajari untuk diterapkan kepada masyarakat. Kegiatan ini tentunya akan menambah wawasan sekaligus melengkapi keterampilan Dosen dan Mahasiswa.

Kegiatan pengabdian kepada masyarakat (PKM) ini diselenggarakan di Desa Bahari III Kecamatan Sampolawa Kabupaten Buton Selatan. Terdapat dua tujuan utama dari implementasi pengabdian masyarakat. Pertama, untuk memberikan penyuluhan mengenai ruang lingkup ekonomi kreatif dan bagaimana mengembangkan ide-ide kreatif menjadi sumber-sumber ekonomi kreatif di desa. Kedua, untuk meningkatkan pengetahuan dan pemahaman masyarakat mengenai manfaat ekonomi kreatif dalam meningkatkan kesejahteraan dan perekonomian desa.

Sementara itu, dari pengabdian masyarakat ini diharapkan masyarakat dapat termotivasi dan lebih percaya diri untuk mengembangkan ide-ide kreatif menjadi sumber-sumber ekonomi kreatif. Selain itu, mereka dapat pula memahami pentingnya pengembangan ekonomi kreatif untuk meningkatkan pendapatan keluarga dan perekonomian desa. Dalam manfaat yang lebih luas adalah berkembangnya kegiatan ekonomi kreatif 
di desa untuk menunjang pembangunan di desa.

PKM ini diterapkan untuk dapat memberi masyarakat kepada masyarakat berupa Pengetahuan, wawasan serta motivasi untuk mengembangkan ide-ide kreatif menjadi usaha-usaha ekonomi kreatif di Desa Bahari III. Dari pola pengabdian tersebut, diharapkan masyarakat dapat meningkatkan pendapatan dan kesejahteraannya melalui pengembangan usaha ekonomi kreatif dengan mengoptimalkan pemanfaatan sumberdaya yang ada di Desa Bahari III.

\section{TINJAUAN PUSTAKA}

Pada intinya, hampir sebagian besar daerah di Indonesia memiliki potensi untuk mengembangkan ekonomi kreatif. Namun perlu diketahui, ekonomi kreatif tidak hanya berupa produk barang saja. Kementerian Pariwisata dan Ekonomi Kreatif di bawah kepemimpinan Mari Elka Pangestu (2011-2014) telah mencatat sebanyak 15 jenis ekonomi kreatif, diantaranya adalah musik, fashion, arsitektur, periklanan, pasar barang seni, kerajinan, desain, film/video/fotografi, permainan interaktif, seni pertunjukan, penerbitan dan percetakan, layanan komputer dan piranti lunak, riset dan pengembangan, dan kuliner. Untuk itu diperlukan aktivasi ekonomi kreatif yang dapat dimulai dari penguatan lokalitas di desa karena sejatinya desa masih menyimpan beragam sisi keunikan dan SDM yang terbilang cukup kreatif.

Sebuah konsep di era baru yang mengintensifkan informasi dan kreatifitas dengan mengandalkan ide dan pengetahuan dari sumberdaya manusianya sebagai faktor produksi yang utama sering disebut dengan ekonomi kreatif. Istilah ini sudah dikenal sejak tahun 2006, namun, perencanaan pengembangan 14 sub sektor ekonomi dalam industri kreatif baru dimulai di tahun 2009 sejak Inpres No.6 Tahun 2009 sebagai Tahun Indonesia Kreatif dikeluarkan. Berdasarkan Peraturan Presiden Nomor 92 Tahun 2011, pemerintah secara resmi membentuk Kementrian Pariwisata dan Ekonomi Kreatif yang bertanggung jawab dalam pengembangan ekonomi kreatif di Indonesia baik Ekonomi Kreatif Berbasis Seni dan Budaya maupun Ekonomi Berbasis Media, Desain dan IPTEK (Hasanah, 2015).

Di Indonesia, memasuki milenium kedua, Pemerintah menetapkan UndangUndang No 22 Tahun 1999 tentang Pemerintahan Daerah yang merupakan penanda dimulainya era desentralisasi (red: otonomi daerah), yang bertujuan mewujudkan tata kelola kepemerintahan yang baik (good governance), penyedia pelayanan publik dan peningkatan daya saing daerah menuju masyarakat sejahtera. 
Hal tersebut menciptakan keakraban masyarakat dengan ekonomi kreatif yang diwujudkan melalui industri rumah kreatif (creative home industri) yang menjual ide kreatif untuk menghasilkan pendapatan.

Para pakar menyebutnya dengan istilah "ekonomi kreatif" yakni sebuah "talenta ekonomi" baru yang mengubah kehidupan masyarakat melalui ide/gagasan kreatif, yang menghasilkan produk-produk bernilai tambah ekonomi yang mampu menjadikan kehidupan lebih sejahtera (Nur Azizah, 2017). Ekonomi kreatif sebagai ekonomi yang menjadikan kreatifitas, budaya, warisan budaya dan lingkungan sebagai tumpuan masa depan (Hasanah, 2015).

Dengan besarnya ekspektasi pertumbuhan sektor ekonomi kreatif, kita dihadapkan pada tantangan untuk dapat menstimulasi terciptanya bentuk-bentuk kreatifitas yang memiliki nilai lebih tinggi, termasuk nilai ekonomi dan kontribusinya bagi perekonomian. Tuntutan untuk mengembangkan ekonomi dengan mengandalkan pengetahuan dan ide atau bisa disebut ekonomi kreatif semakin menguat seiring dengan semakin kompleksnya perubahan lingkungan. Jika masa lalu manusia menebang kayu kemudian dijual gelondongan, maka manusia sekarang lebih kreatif, diwujudkan dalam bentuk kerajinan tangan jenis kursi, lemari, meja, alat-alat makan, miniatur hiasan rumah, dll. Ekonomi kreatif merupakan aktifitas perekonomian yang lebih mengandalkan ide atau gagasan (kreatif) untuk mengelola material yang bersumber dari lingkungan di sekitarnya menjadi bernilai tambah ekonomi (Dermawan, 2016).

\section{METODE PELAKSANAAN}

Pelaksanaan PKM dilaksanakan di Desa Bahari III Kecamatan Sampolawa Kabupaten Buton Selatan, pada tanggal 25 -27 November 2019.

Sasaran dari kegiatan penyuluhan ini adalah warga masyarakat Desa Bahari III yang terdiri dari Kepala Keluarga yang berminat terhadap pengembangan ekonomi kreatif di Desa Bahari III.

Tahapan Kegiatan PKM terdiri dari beberapa tahapan sebagai berikut:

1. Mengadakan pertemuan dengan Kepala Desa Bahari III guna mendapatkan izin pelaksanaan dan penetapan jadwal kegiatan.

2. Mengadakan pertemuan sesama Tim PKM untuk mendiskusikan materi kegiatan yang akan dilaksanakan.

3. Mempersiapkan bahan atau materi yang diperlukan pada penyuluhan penguatan ekonomi kreatif berbasis sumberdaya desa bagi masyarakat Desa Bahari III. 
4. Mengadakan penyuluhan mengenai penguatan ekonomi kreatif berbasis sumberdaya desa di Desa Bahari.

\section{HASIL DAN PEMBAHASAN}

Dalam pelaksanaannya kegiatan penyuluhan ini dihadiri oleh berbagai lapisan masyarakat. Tokoh masyarakat yang hadir antara lain Bapak Kepa Desa Bahari III, Perangkat Desa Bahari III, Kepala Dusun. Selain tokoh masyarakat juga dihadiri oleh masyarakat (Kepala Keluarga) yang berminat terhadap pengembangan ekonomi kreatif di Desa Bahari III.

Potensi sumberdaya desa di Desa Bahari III sangat beragam dan prospek dikembangkan untuk mendukung geliat ekonomi kreatif masyarakat. Sumberdaya yang dapat mendukung ekonomi kreatif masyarakat antara lain sumberdaya pertanian (kelapa), sumberdaya perikanan (ikan, udang, dan lain-lain), sumberdaya wisata (pantai). Desa Bahari III memiliki tempat yang sangat menarik untuk dikembangkan sebagai upaya meningkatkan kesejahteraan. Sumberdaya yang terpenting yang dimiliki adalah sumberdaya insani yang dimiliki desa untuk pengembangan ekonomi kreatif.

Masyarakat yang hadir tampak sangat antusias mendengarkan penyuluhan yang disampaikan, hal ini tampak dari banyaknya masyarakat yang bertanya dan ingin mendapatkan penjelasan lebih mendalam bagaimana ekonomi kreatif bisa mereka kembangkan di wilayah desa mereka.

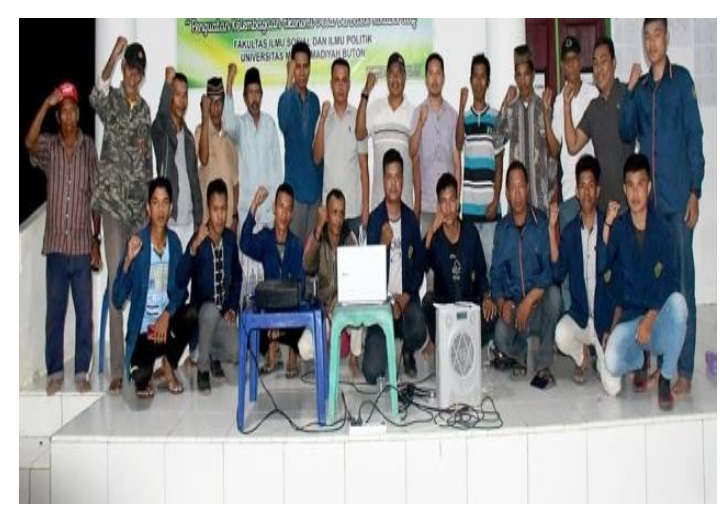

Gambar 1. Tim PKM dan Tokoh Masyarakat

Kegiatan penyuluhan dilakukan dengan metode ceramah dan tanya jawab. Materi penyuluhan yang disampaikan disesuaikan dengan potensi sumberdaya yang ada di desa. Materi penyuluhannya antara lain mengenai pemahaman apa yang dimaksud dengan ekonomi kreatif, apa itu kreatifitas, bagaimana proses pengolahan sabut kelapa, bagaimana proses pengolahan tempurung kelapa, produkproduk olahan kreatif lainnya. Selain metode ceramah, tanya jawab materi juga disampaikan dengan pemutaran serta mempertontonkan vidio proses-proses pembuatan produk kreatif masyarakat pedesaan dari daerah lain. Pemutaran vidio ini juga bermaksud untuk memotivasi keinginan masyarakat untuk mengembangkan ide-ide kreatif yang 
dimiliki untuk memanfaatkan sumberdaya yang tersedia di wilayahnya. Sehingga masyarakat menjadi lebih cepat pemahamannya dan tertarik mengikuti penyuluhan hingga selesai.

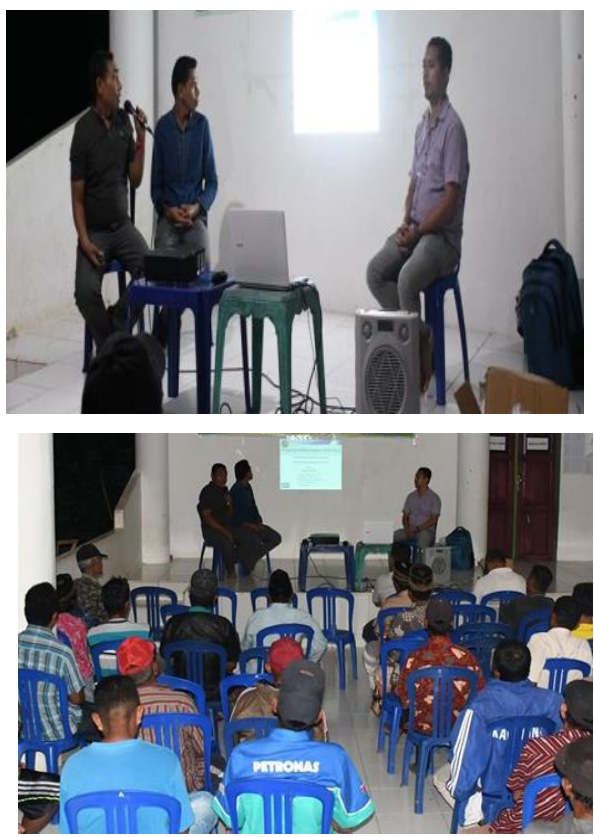

Gambar 2. Penyuluhan Tim PKM

Pelaksanaan penyuluhan yang diberikan kepada masyarakat sudah merupakan langkah tepat untuk memotivasi selera usaha masyarakat. Adanya hubungan peranan penyuluhan terhadap peningkatan pendapatan masyarakat di pedesaan merupakan suatu hasil dari proses penyuluhan yang telah dilaksanakan. Melalui penyuluhan masyarakat mendapatkan informasi dan wawasan, sehingga masyarakat dapat memahami secara mendalam tentang ekonomi kreatif serta manfaatnya bagi peningkatan pendapatannya.

\section{KESIMPULAN}

Kegiatan PKM ini memiliki fungsi penyuluhan, aktifitas masyarakat setempat, dengan mudah menerima pengetahuan baru dan berkeinginan mengimplementasikannya. Namun untuk memperoleh hasil yang lebih maksimal hal yang dapat dilakukan adalah diperlukan kegiatan lanjutan yang bersifat pendampingan masyarakat sehingga mereka terus bisa menekuni usaha yang akan dibuat. Pelaksanaan penyuluhan yang diberikan kepada masyarakat sudah merupakan langkah tepat untuk memotivasi selera usaha masyarakat.

Melalui penyuluhan, masyarakat mendapatkan informasi dan wawasan, sehingga masyarakat dapat memahami secara mendalam tentang ekonomi kreatif serta manfaatnya bagi peningkatan pendapatannya. Namun untuk memperoleh hasil yang lebih maksimal hal yang dapat dilakukan adalah diperlukan kegiatan lanjutan yang bersifat pendampingan masyarakat sehingga mereka terus bisa menekuni usaha yang akan dibuat.

\section{DAFTAR PUSTAKA}

Bourdiau, P. And Wacquant, L. 1992. An Invitation to Reflexive ociology. Chicango. University of Chicango Press. 
Dermawan, A. M. (2016). Pemberdayaan perempuan melalui kegiatan ekonomi kreatif abdurraafi' maududi dermawan. Studi Gender Dan Anak, 03, 159-172.

Hasanah, L. L. N. El. (2015).

Pengembangan Wirausaha Muda

Ekonomi Kreatif Berbasis Budaya di Daerah Istimewa Yogyakarta. Jurnal Studi Pemuda, 4(2), 268-280.
Nur Azizah, S. (2017). Pengembangan Ekonomi Kreatif Berbasis Kearifan Lokal Pandanus Handicraft dalam Menghadapi Pasar Modern Perspektif Ekonomi Syariah (Study Case di Pandanus Nusa Sambisari Yogyakarta). APLIKASIA: Jurnal Aplikasi Ilmu-Ilmu Agama, 17, 6378.

Sudarmo, 2011. Isu-Isu Administrasi Publik dalam Perspektif Governance, Surakarta: Smart Media 